\title{
Comparison of enzyme-linked immunosorbent assay (ELISA) technique and complement-fixation test for estimation of cytomegalovirus IgG antibody
}

\author{
J. C. BOOTh, Gillian HANNINGton, T. A. G. AZIZ, AND H. STERN \\ From the Department of Virology, St George's Hospital Medical School (University of London), \\ Hyde Park Corner, London SWI, UK
}

SUMMARY The ELISA technique has been found to be reliable for the detection and titration of cytomegalovirus-specific IgG antibody in serum. It is about six times more sensitive than the CF test although some discrepancies were found between the antibody titres determined by the two methods.

Cytomegalovirus (CMV) is an important cause of fetal damage and of opportunistic infection in immunosuppressed patients. Serological diagnosis of infection has relied heavily on the complementfixation (CF) test, although more recently the immunofluorescence technique has been widely used to detect both IgG and IgM antibody (Hanshaw et al., 1968; Thé et al., 1974; Betts et al., 1976). Other techniques, such as passive heamagglutination (Bernstein and Stewart, 1971; Fuccillo et al., 1971), immune adherence (Dienstag et al., 1976), and radioimmunoassay (Forghani et al., 1976; Knez et al., 1976), have also been used and found to be satisfactory but have not been generally adopted.

The latest technique is the enzyme-linked immunosorbent assay (ELISA) (Engvall and Perlmann, 1972; Voller et al., 1976), which has been shown to be more sensitive than passive haemagglutination for detecting IgG antibody (Castellano et al., 1977) and comparable in sensitivity to immunofluorescence for detecting IgM antibody (Schmitz et al., 1977). The present report compares the ELISA technique with the CF test in examining for CMV-specific IgG antibody in sera from patients.

\section{Material and methods}

\section{PREPARATION OF ANTIGENS}

Confluent monolayers of MRC-5 diploid human fibroblasts (Jacobs et al., 1970) were grown in Roux bottles. They were infected with CMV strain AD 169 , at a multiplicity of $0 \cdot 1$ plaque-forming units per cell, and then incubated in Eagle's minimal

Received for publication 19 July 1978 essential medium with $10 \%$ fetal calf serum at $37^{\circ} \mathrm{C}$. After 7-10 days, when gross cytopathic effects had developed, the cells were scraped off the bottles into a small volume of phosphate-buffered saline (PBS), pH 7.2, washed three times in PBS, and resuspended in a volume of $0.1 \mathrm{M}$ glycine- $\mathrm{NaCl}-$

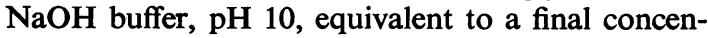
tration of $1 \mathrm{ml}$ per culture bottle of cells. The concentrated cells were immediately disrupted by ultrasonication for $5 \mathrm{~s}$ and the cellular debris was removed by centrifugation at $800 \mathrm{~g}$ for $10 \mathrm{~min}$. The final supernatant was stored, in $0.25 \mathrm{ml}$ quantities, at $-70^{\circ} \mathrm{C}$. Control antigen was prepared in the same way from uninfected MRC-5 cells. These antigens were used for both the CF and ELISA tests.

COMPLEMENT-FIXATION TEST

This was carried out by the microtitre technique (Sever, 1962) with 2 units of antigen and 3 MHD $_{50}$ of complement. Antibody titres were read as the reciprocal of the highest dilution of serum giving $50 \%(2+)$ fixation.

\section{ELISA PROCEDURE}

This was done by the method of Voller et al. (1976). Flat-bottomed wells in polystyrene microtitre plates (Cooke Microtitre M29AR, Dynatech Ltd) were coated with viral or control antigen by the addition of $0.3 \mathrm{ml}$ of the antigen, diluted to optimal concentration in $0.1 \mathrm{M}$ carbonate-bicarbonate buffer, pH 9.6, and incubated overnight. The plates were then washed three times in PBS containing $0.05 \%$ Tween 20 and $0.02 \% \mathrm{NaN}_{3}$ (PBST) and shaken dry. They were used immediately or after storage at $-70^{\circ} \mathrm{C}$ (stored plates were found to be satisfactory 
even after nine months). Test sera were diluted in PBST, and $0.3 \mathrm{ml}$ of each dilution was added to duplicate wells. The plates were incubated overnight at $4^{\circ} \mathrm{C}$, washed three times in PBST, and shaken dry. Conjugate was then added, in $0.3 \mathrm{ml}$ amounts, and the plates were left for $2 \mathrm{~h}$ at room temperature. After three further washes in PBST, $0.3 \mathrm{ml}$ of the substrate was added to each well. Exactly $30 \mathrm{~min}$ later the reaction was stopped by the addition of $0.05 \mathrm{ml}$ of $3 \mathrm{M} \mathrm{NaOH}$. The intensity of the colour change produced in the substrate was measured at $400 \mathrm{~nm}$ in a Gilford 300-T-1 spectrophotometer with a vacuum-aspirated microcuvette accessory. The absorbance (E400) for each serum sample was calculated as the mean of the duplicate readings minus the 'background' activity in the test; the latter was measured as the mean of the readings from four duplicate wells incubated with PBST instead of serum.

\section{PHOSPHATASE SUBSTRATE}

This was a $0 \cdot 1 \%$ solution $(w / v)$ of $p$-nitrophenyl phosphate in $10 \%$ diethanolamine buffer, $\mathrm{pH} \mathrm{9.8,}$ with $0.02 \% \mathrm{NaN}_{3}$ and $0.01 \% \mathrm{MgCl}_{2} .6 \mathrm{H}_{2} \mathrm{O}$.

\section{CONJUGATE}

The conjugate was sheep anti-human-IgG antiserum labelled with alkaline phosphatase (Type VII, Sigma Chemical Co) by the method of Voller et al. (1976). The working dilution was determined by coating the wells of microtitre plates with a $1 / 100$ dilution of viral antigen, challenging with a $1 / 100$ dilution of a pool of CMV CF antibody-positive human sera, and then adding, to duplicate wells, a range of conjugate dilutions from 1 in 100 to 1 in 2000 . A control test was set up at the same time with a 1 in 100 dilution of control antigen. The highest dilution of conjugate that gave an E400 reading of 1.0 with the viral antigen, compared with 0.05 with the control antigen, was 1 in 400, and this was used as the working dilution in all subsequent tests.

\section{DETERMINATION OF OPTIMAL}

\section{CONCENTRATION OF ANTIGEN}

This was determined by a 'chess-board' titration against the CF antibody-positive human serum pool. Duplicate wells were coated with doubling dilutions of viral antigen or control antigen and challenged with doubling dilutions of antiserum. The E400 readings for each dilution of the antigens were plotted against the serum dilutions (Fig. 1). The highest reading, indicating saturation of binding sites on the surface of the microtitre wells, was achieved with a 1 in $\mathbf{4 0 0}$ dilution of the viral antigen.

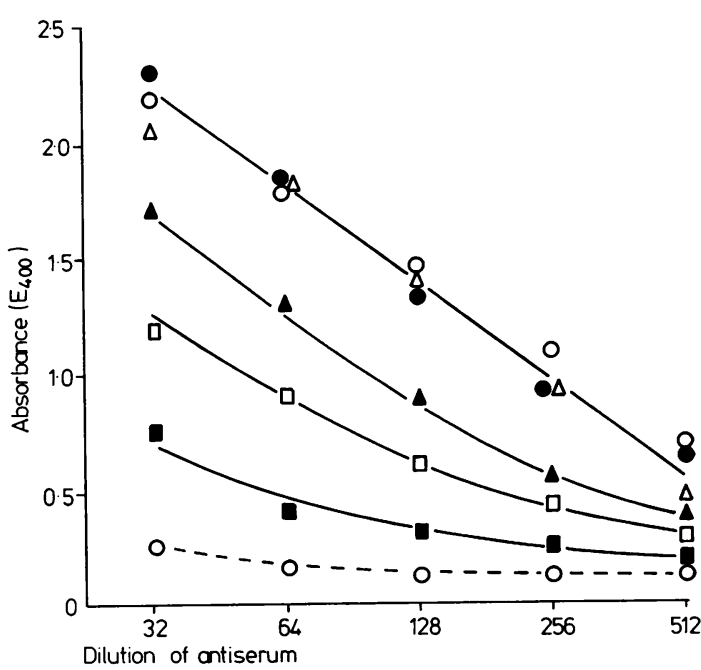

Fig. 1 E400 values of serial dilutions of CMV antigen in the presence of increasing dilutions of specific antiserum. Dilutions of antigen: $\mathrm{O}-\mathrm{O}=1$ in 100; $-O=1$ in 200; $\triangle-\triangle=1$ in 400; $\triangle-\Delta=1$ in 800; $\square-\square=1$ in $1600 ; \square-\square=1$ in 3200 . $\bigcirc \cdots=$ control, uninfected host-cell antigen.

\section{Results}

RELATIONSHIP OF E400 VALUES TO CONCENTRATION OF CMV ANTIBODY IN TEST SERA

Preliminary studies were carried out with 33 antisera, four devoid of CF antibody (titre $<8$ ) and 29 with CF antibody titres ranging from 32 to 5792 . Doubling dilutions of each serum were examined by the ELISA technique, and their E400 values were plotted on a graph against serum dilution. Figure 2 shows the results from eight representative sera, two CF antibody-negative and six CF antibodypositive. Sera without antibody (CF antibody titre $<8)$ commonly gave, at low dilutions, some minimal reactivity (always $<0 \cdot 25$ ). This was probably due to nonspecific, residual attachment of serum or conjugate since similar low readings were obtained from wells that had been coated with control antigen or pretreated only with PBST. The curves for the antibody-positive sera, particularly those with higher titres, were obviously sigmoid in form. However, whether the antibody titre was high or low (CF antibody titres 32-5792), the body of the curve, over a wide range of serum dilutions, was rectilinear. Moreover, the curves over their rectilinear sections, for all 29 positive sera examined, were found to be closely parallel, indicating that a standard curve could be used to determine the ELISA antibody titre of each serum from the E400 value 


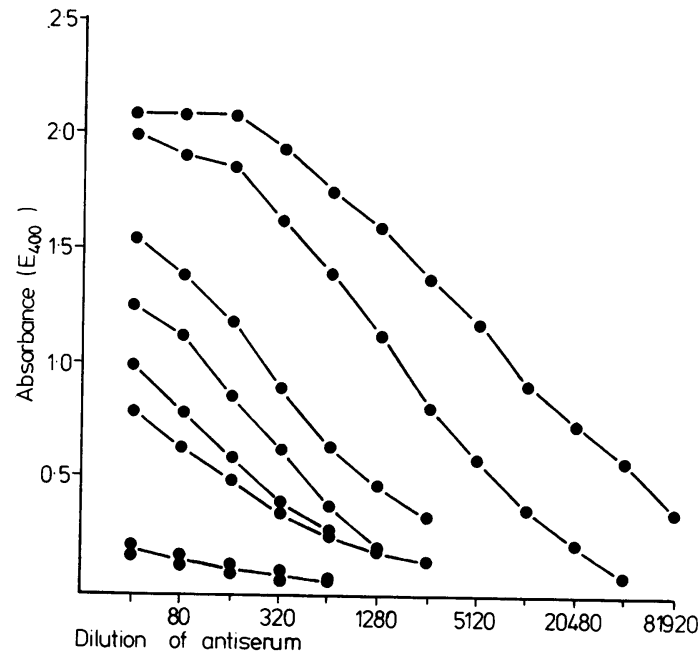

Fig. 2 Relationship between antibody concentration and $E 400$ values in six known CMV antibody-positive (CF antibody titres 32-5792) and two antibody-negative (CF antibody titre $<8$ ) sera.

obtained from any single suitable dilution of that serum.

The ELISA antibody titre of each of the 29 sera was measured, from their curves described above, as the reciprocal of the dilution that had an E400 value of 0.5 , and this was plotted on a graph against the E400 value obtained for a 1 in 300 dilution of the same serum (Fig. 3); 1 in 300 was chosen as a suitable dilution from Fig. 2, which showed that it lay on the linear part of curves representing both high-titred and low-titred antisera. A straightline, directly proportional relationship was obtained (correlation coefficient $r=0.93, \mathrm{P}<0.001$ ), confirming that the antibody titre of a serum could be reliably calculated from the $\mathrm{E} 400$ value of a single 1 in 300 dilution. The lowest E400 reading among the 29 positive sera examined at this dilution was $0 \cdot 22$; the readings for the four negative sera were all $<0.09$; 1 in 300 was, therefore, used as the standard test dilution for sera in subsequent experiments.

COMPARISON OF ELISA AND CF TESTS FOR DETECTION OF ANTIBODY

A single batch of antigen was used to examine the 29 CMV-antibody-positive antisera described above by both the ELISA and the CF techniques. The results obtained by the two techniques, that is, the $\mathrm{E} 400$ values at a 1 in 300 dilution and the CF antibody titres, showed good correlation $(r=0.73$, $P<0.001$ ) (Fig. 4), although a few sera with almost identical E400 values had CF antibody titres

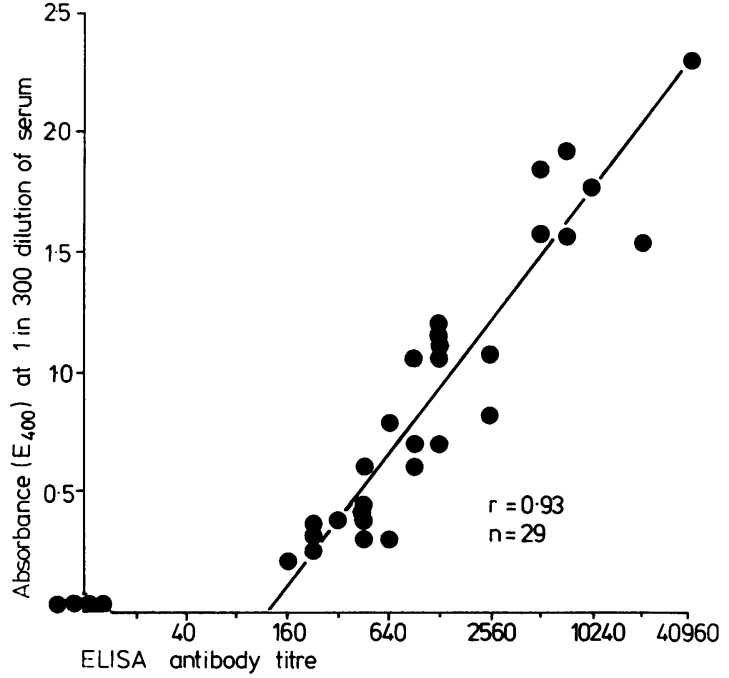

Fig. 3 Comparison of the ELISA antibody titres of 33 sera, calculated from the highest dilution of serum giving an E400 value of 0.5, with the E400 values of the same sera examined at a 1 in 300 dilution.

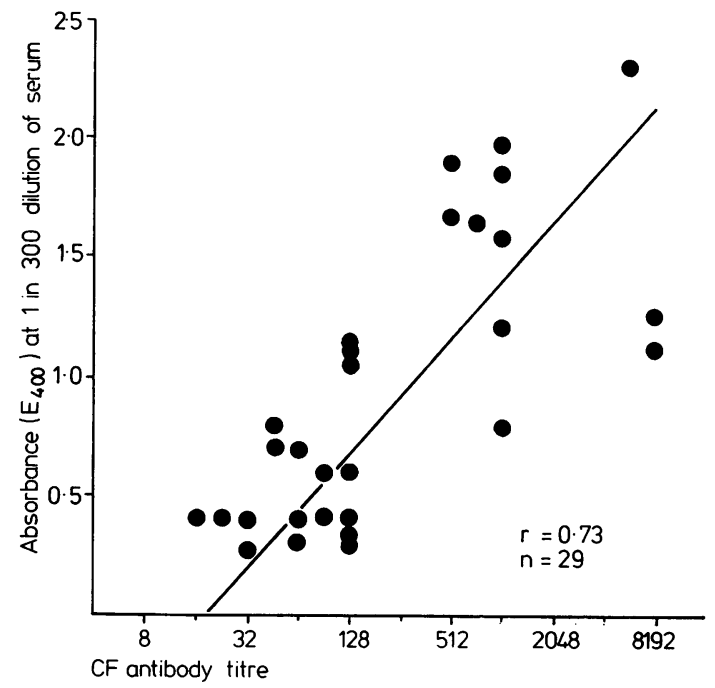

Fig. 4 Comparison of the CF antibody titres of 29 $C M V$ antibody-positive sera against the E400 values of the same sera examined at a 1 in 300 dilution.

that differed as much as 64-fold. Extrapolation of the regression curves to the abscissae on Figs 3 and 4 showed that the ELISA technique was about six times more sensitive than $\mathrm{CF}$ for detection of CMV antibody.

To examine further the relationship between the ELISA and CF tests, a larger batch of 90 sera, 
randomly collected from patients in hospital, was tested. Twenty-one had CF antibody titres of $<8$ and E400 values, at a 1 in 300 dilution, of 0.04-0.13 (mean 0.08, standard deviation 0.03). Sixty-nine sera had CF antibody titres of 16-8192 and E400 values of $\mathbf{0} \cdot 24-2 \cdot 32$. Again there was good general agreement between the two tests $(r=0.62, P<$ 0.001), but some scatter of results (Fig. 5). Sera with CF antibody titres of 64 or less had E400 values of $<1.0$, and those with titres of $>1024$ had E400 values of $>1 \cdot 0$, but among the sera with intermediate CF antibody titres of 128-1024 there was a scatter of E400 values, ranging from 0.24 to $2 \cdot 0$. However, examination by ELISA at a 1 in 300 dilution effectively discriminates between antibodynegative sera (CF antibody titre $<8, \mathrm{E} 400<0.2)$ and antibody-positive sera (CF $>16, \mathrm{E} 400>0 \cdot 2)$. None of the 90 sera showed any significant reactivity in either the CF or ELISA tests against control, uninfected antigen; they were negative for rheumatoid factor when tested at a 1 in 10 dilution by latex agglutination and were not anticomplementary in the CF test.

The reproducibility of the CF and ELISA results was determined by examining the 29 original positive sera on three separate occasions. Their CF antibody titres varied by no more than twofold and their E400 values by only $19 \%-32 \%$ (mean $25 \%$ ). A further test foi reproducibility was carried out by fractionating six of the sera on $15 \%-35 \%(w / w)$ sucrose gradients, for $18 \mathrm{~h}$ at $35000 \mathrm{rpm}$, in the Beckman SW 40 rotor, and examining the various fractions for antibody. Clearly related curves were

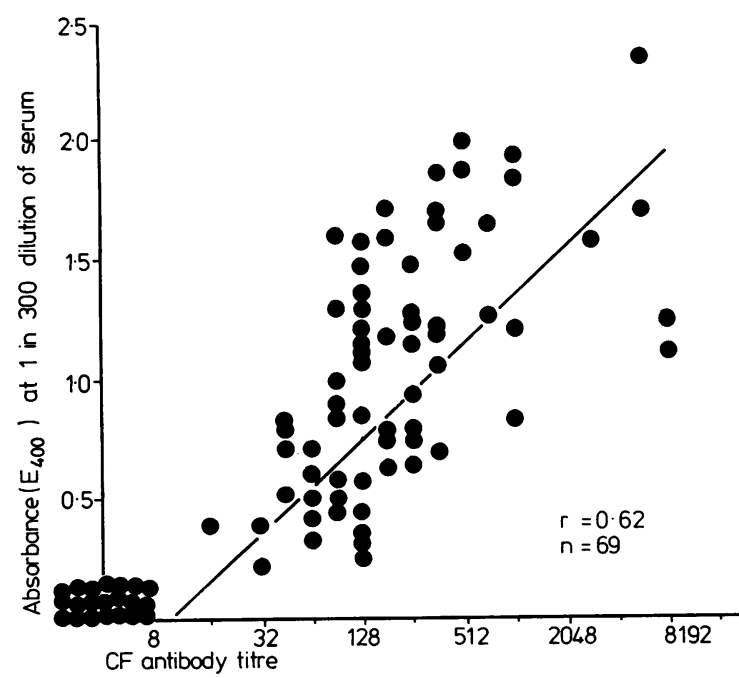

Fig. 5 Comparison of the CMV CF antibody titres of 90 randomly collected sera with the $E 400$ values of the same sera examined at a 1 in 300 dilution.

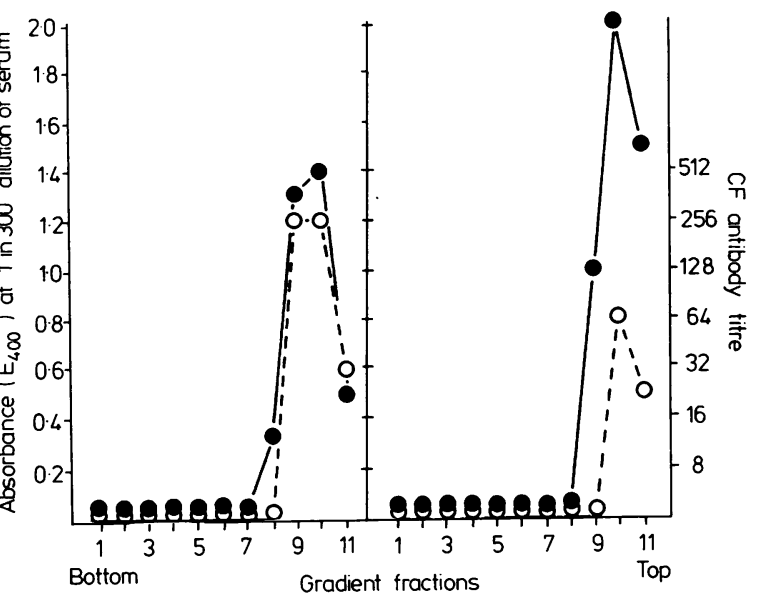

Fig. 6 Comparison of the ELISA and CF tests for detecting the presence of CMV antibody in sucrose gradient fractions of two sera. - $=E 400$ values at a 1 in 300 dilution of each gradient fraction; $\bigcirc-O=C F$ antibody titre.

obtained for the two techniques with all six sera; results for two of them are shown (Fig. 6).

\section{Discussion}

Previous studies have shown that the ELISA technique can be readily applied to the detection of CMV antibody, both IgG (Voller and Bidwell, 1976) and IgM (Schmitz et al., 1977), and that it is comparable in sensitivity to the indirect immunofluorescence test (Schmitz et al., 1977) and 2- to 10fold more sensitive than the indirect haemagglutination test (Castellano et al., 1977). The present investigation has shown that it is about six times more sensitive than the CF test. Moreover, the antibody titre, determined by ELISA, was found to be proportional to the absorbance (E400) over a wide range of serum dilutions and can therefore be reliably calculated from the E400 reading obtained for a single dilution of the serum; 1 in 300 was found to be a suitable dilution for this purpose. There was good correlation between the antibody titres obtained by the ELISA and CF techniques and excellent agreement in determining the presence (CF antibody titres 16 and more) or absence (CF antibody titre $<8$ ) of antibody; at the lower levels of CF antibody the E400 readings were twice those obtained for CF antibody-negative sera. However, none of the sera investigated had really low CF antibody titres of $<16$, perhaps because the antigen was a potent, glycine-extracted preparation (Krech et al., 1971; Kettering et al., 1977). Whether exam- 
ining sera at a 1 in 300 dilution in the ELISA test will effectively discriminate at these low levels of antibody requires further investigation.

Nevertheless, although the same antigen was used for both the ELISA and CF tests, there weie frequent discrepancies between the $\mathrm{E} 400$ values and the CF antibody titres, particularly within the middle range of values (Fig. 5). That is, sera with similar E400 values often showed a wide range of $\mathrm{CF}$ antibody titres. This could not be satisfactorily explained by poor reproducibility of either test or by the variable presence of nonspecific inhibitors, such as anticomplementary factors or rheumatoid factor, the presence of which has been shown to depress CF antibody titres in several other virusantibody systems (Stanford, 1972; Haukenes, 1974). Another possibility was the presence in the antigen preparations of the nonspecific, intracytoplasmic $F_{c}$ receptor that develops in CMV-infected cells(Sakuma et al., 1977). Extracted receptor protein could perhaps attach to the microtitre wells and give spuriously enhanced E400 readings due to reaction with antibody other than $C M V$ antibody; $F_{c}$ receptor-antibody complexes do not fix complement and would not interfere with the CF test. This was excluded, however, by the lack of significant reaction in the ELISA test with CMV antibody-negative sera. The simplest explanation would be that human sera contain variable mixtures of CMV IgG antibodies (Cremer et al., 1975), only some of which readily fix complement, whereas the ELISA technique, based on a globulin-antiglobulin reaction mechanism, has a much wider recognition range for antibody. Unfortunately, IgG antibodies that do not fix complement have not been described for CMV, but since similar discrepancies have been recognised between the CF test and both the indirect and anticomplement immunofluorescence techniques (Griffiths et al., 1978), they deserve further investigation.

We are indebted to the South West Thames Regional Health Authority for generous financial support for these investigations.

\section{References}

Bernstein, M. T., and Stewart, J. A. (1971). Indirect hemagglutination test for detection of antibodies to cytomegalovirus. Applied Microbiology, 21, 84-89.

Betts, R. F., George, S. D., Rundell, B. B., Freeman, R. B., and Douglas, R. G., Jr. (1976). Comparative activity of immunofluorescent antibody and complement-fixing antibody in cytomegalovirus infection. Journal of Clinical Microbiology, 4, 151-156.

Castellano, G. A., Hazzard, G. T., Madden, D. L., and Sever, J. L. (1977). Comparison of the enzyme-linked immunosorbent assay and the indirect hemagglutina- tion test for detection of antibody to cytomegalovirus. Journal of Infectious Diseases, 136, S337-S340.

Cremer, N. E., Schmidt, N. J., Jensen, F., Hoffman, M., Oshiro, L. S., and Lennette, E. H. (1975). Complement-fixing antibody in human sera reactive with viral and soluble antigens of cytomegalovirus. Journal of Clinical Microbiology, 1, 262-267.

Dienstag, J. L., Cline, W. L., and Purcell, R. H. (1976). Detection of cytomegalovirus antibody by immune adherence hemagglutination. Proceedings of the Society for Experimental Biology and Medicine, 153, 543-548.

Engvall, E., and Perlmann, P. (1972). Enzyme-linked immunosorbent assay, ELISA. III Quantitation of specific antibodies by enzyme-labeled anti-immunoglobulin in antigen-coated tubes. Journal of Immunology, 109, 129-135.

Forghani, B., Schmidt, N. J., and Lennette, E. H. (1976). Antisera to human cytomegalovirus produced in hamsters: reactivity in radioimmunoassay and other antibody assay systems. Infection and Immunity, 14, 1184-1190.

Fuccillo, D. A., Moder, F. L., Traub, R. G., Hensen, S., and Sever, J. L. (1971). Micro indirect hemagglutination test for cytomegalovirus. Applied Microbiology, 21, 104-107.

Griffiths, P. D., Buie, K. J., and Heath, R. B. (1978) A comparison of complement-fixation (CF), indirect immunofluorescence for viral late antigens (IFA-LA), and anti-complement immunofluorescence (ACIF) tests for the detection of cytomegalovirus-specific serum antibodies. Journal of Clinical Pathology, 31, 827-831.

Hanshaw, J. B., Steinfeld, H. J., and White, C. J. (1968). Fluorescent-antibody test for cytomegalovirus macroglobulin. New England Journal of Medicine, 279, 566-570.

Haukenes, G. (1974). Negative complement-fixation tests with rheumatoid factor positive sera. Annals of the Rheumatic Diseases, 33, 461-464.

Jacobs, J. P., Jones, C. M., and Baille, J. P. (1970). Characteristics of a human diploid cell designated MRC-5. Nature, 227, 168-170.

Kettering, J. D., Schmidt, N. J., and Lennette, E. H. (1977). Improved glycine-extracted complement-fixing antigen for human cytomegalovirus. Journal of Clinical Microbiology, 6, 647-649.

Knez, V., Stewart, J. A., and Ziegler, D. W. (1976). Cytomegalovirus specific IgM and IgG response in humans studied by radioimmunoassay. Journal of Immunology, 117, 2006-2013.

Krech, U., Jung, M., and Sonnabend, W. (1971). A study of complement-fixing, immunofluorescent, and neutralizing antibodies in human cytomegalovirus infections. Zeitschrift für Immunitätsforschung, 141, 411-429.

Sakuma, S., Furukawa, T., and Plotkin, S. A. (1977). The characterization of IgG receptor induced by human cytomegalovirus. Proceedings of the Society for Experimental Biology and Medicine, 155, 168172.

Schmitz, H., Doerr, H. W., Kampa, D., and Vogt, A. (1977). Solid-phase enzyme immunoassay for immuno- 
globulin $\mathrm{M}$ antibodies to cytomegalovirus. Journal of Clinical Microbiology, 5, 629-634.

Sever, J. L. (1962). Application of a microtechnique to viral serological investigations. Journal of Immunology, 88, 320-329.

Stanford, F. (1972). Comparison of complement-fixing antibody titres in patients with rheumatoid arthritis and matched controls. Annals of the Rheumatic Diseases, 31, 330-333.

Thé, T. H., Klein, G., and Langenhuysen, M. M. A. C. (1974). Antibody reactions to virus-specific early antigens (EA) in patients with cytomegalovirus (CMV) infection. Clinical and Experimental Immunology, 16, 1-12.
Voller, A., and Bidwell, D. E. (1976). Enzyme-immunoassays for antibodies in measles, cytomegalovirus infections and after rubella vaccination. British Journal of Experimental Pathology, 57, 243-247.

Voller, A., Bidwell, D., and Bartlett, A. (1976). Microplate enzyme immunoassays for the immunodiagnosis of virus infections. In Manual of Clinical Immunology, edited by N. R. Rose and H. Friedman, pp. 506-512. American Society for Microbiology, Washington, DC.

Requests for reprints to: Professor H. Stern, Department of Medical Microbiology, St George's Hospital Medical School, Hyde Park Corner, London SW1, UK. 